\title{
Danish council fails to satisfy its critics
}

Paris. Danish scientists are claiming that the recently-created Danish National Research Foundation, set up with the proceeds of the privatization of a number of publicly-owned insurance companies, has spent its first round of five-year grants in ways that fall far short of its goal of "funding unique Danish research at the international level."

Two years ago, the government decision to create the research council with the $\mathrm{DKr}$ 2 billion (US\$297 million) proceeds of the privatization raised protests from scientists, who described it as a "cigar box", the Danish term for political earmarking (see Nature 360,$517 ; 1992$ ). They argued that the money would be better spent through the country's existing five research councils. The government apparently wanted to avoid spreading the money too thinly, and to control how it was spent.

The foundation has set out to provide substantial grants to research groups which are of international standing and capable of managing a large research effort. To qualify, the research proposed must not be well supported through existing channels, and must also open up new possibilities for international collaboration.

In addition, research supported by the foundation must be "relevant to Denmark from a cultural point of view, or because of demands from the public or private sector."

Whatever their feelings about the goals of the foundation, many Danish researchers have expressed surprise at some of the 23 research groups chosen by the foundation to share DKr750 million of funding over the next five years. "Everyone here was extremely disturbed and alarmed about the distribution" says one senior researcher on the medical faculty of the University of Copenhagen, claiming for example that many of the winners have had a poor publication record, lack experience, and are only "loosely connected to the international scientific community".

The foundation's nine-member board short-listed 50 applications from the 350 it received. Peder Olsen Larsen, the Aarhus chemist who is the foundation's first chairman, says it was impossible to send all 350 applications out to external review (the referees were paid). "You don't need to be an expert to see if people are international, or if their research plan is coherent," says Larsen. The fifty short-listed proposals were sent out to foreign referees; but the board had the final say in who received grants.

The board was appointed in 1991 by Bertel Heerder, the then research minister. He nominated Larsen as chairman, and Ulrik Lassen, senior vice-president of Novo Nordisk, as deputy chairman. Heerder also chose seven other board members from candidates proposed by the research councils and other scientific bodies.

Jens Rehfeld, an endocrinologist at Copenhagen University Hospital who had his application to create a peptide centre rejected despite very favourable reports from foreign referees, criticizes the fact that the board's members are no longer active scientists. Rehfeld also argues that nine individuals cannot have sufficient expertise to cover all fields of science and the humanities.

One individual close to the board agrees with both of Rehfeld's assertions. But he says that the referees provided the necessary scientific expertise. And a board member, answering the charge that not all the groups selected for support already enjoy an international reputation, admits that in some cases the foundation selected "groups who are not yet strong, but who we expect will be

\section{CNRS moves home - and cuts down on staff}

Paris. France's Centre National de la Recherche Scientifique (CNRS) has opened a new headquarters at the Michel-Ange campus in southeast Paris. The organization, which is France's main source of funds for basic research, says that the move from the centre of Paris to the new site, which comprises five modern buildings and a mansion built in 1710 , symbolizes a shift in the priority of its administration from day-to-day management to a greater con-

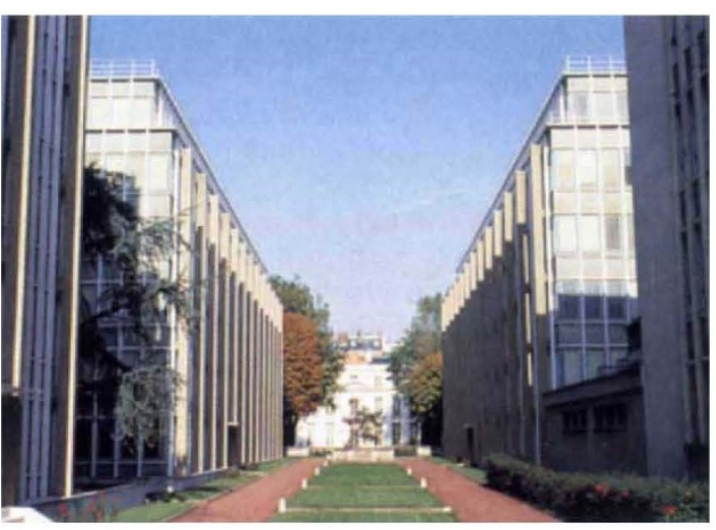

cern with steering policy. To this end, the new site brings together the administration's seven scientific departments, its national committee, and Institutes of Sciences of the Universe, and of Nuclear and
Particle Physics, which were previously scattered between seven sites around Paris. At the same time, the CNRS has trimmed the number of administrators from 1,100 to 700 .
D.B. given this money". Rehfeld claims, however, that the board superimposed additional criteria, which he describes as political, on the referees' assessments.

Larsen defends the choice of winners, and points out that these were agreed unanimously by the whole board. Board members - and some other scientists - also point out that controversy is to be expected whenever large amounts of money are distributed, especially when decisions have to be made on projects covering all academic disciplines.

How well the foundation has spent what represents a significant share of the Danish research budget will become known in 1996 , when external reviewers evaluate the selected projects, and recommend if they should continue to be funded. Meanwhile falling interest rates threaten to reduce the return on the foundation's capital, and to leave it with little money to distribute in its next funding round, due in 1998.

\section{Declan Butler}

\section{UK rules out new gene therapy laws}

London. Britain has for the time being ruled out new legislation regulating the field of gene therapy. Tom Sackville, the Parliamentary Secretary for Health, told a meeting in London on Monday organized by the Bioindustry Association that the British government felt a legislative approach to an evolving field "would not be appropriate".

Sackville also used the opportunity to announce the sixteen members of a new Genetic Therapy Advisory Committee. This committee will replace the Committee on the Ethics of Gene Therapy, which has been chaired by Sir Cecil Clothier. It will be headed by Dame June Lloyd, formerly professor of child health at the Institute of Child Health, London.

The new committee will review all proposals for gene therapy research on human subjects in Britain, and will advise Mrs Virginia Bottomley, the health minister, on technical developments in gene therapy and their implications. Its members range from geneticist Martin Bobrow and theologian Keith Denison to the broadcaster and journalist Nick Ross, and Brian Richards, chairman of British Bio-technology Ltd.

Bob Williamson, professor of biochemistry at St Mary's Hospital Medical School in London, who is closely involved in gene therapy trials of a potential treatment for cystic fibrosis, says that the latest announcement should act as a stimulus for European biotechnology companies. Unlike their counterparts in the United States, he said, European companies had not "gripped the nettle" of gene therapy. 